\title{
CAPITAL MODEL PRISON: A POLITICAL TOOL FOR GOVERNMENT POWER
}

\author{
WEIQI CHU \\ Department of Architecture, DAAP, University of Cincinnati, USA
}

\begin{abstract}
Beijing Prison, also known as Capital Model Prison, was China's first modern prison built after the Republic of China was established in 1912, and functions still as a model of national prison reform. Before its construction, China's prisons were generally regarded as punishment centers. New prison design sought to indoctrinate prisoners and allowed the incarcerated to remain in limited contact with the outside world. The new government introduced modern architectural layouts, incorporating European architectural features while retaining Chinese architectural characteristics. The Qing government originally built this prison to perpetuate class rule, but the Republic of China government refined and adapted it to popularize politics. As a dictatorship tool it served the ruling class, although this did not necessarily rule out its positive contributions to political and historical change. This research explores why the prison was built and describes its intended purpose. It also considers the prison's spatial layout, and its potential to serve as a model for a new generation of Chinese prisons. In particular, it shows how its establishment enabled the government to popularize new ideas during changing historical periods, highlighting the prison's influence on society and culture, and its underlying exemplary symbolic significance.
\end{abstract}

Keywords: architectural, political, Capital Model Prison, transformation, culture, social.

\section{INTRODUCTION}

As confinement centers, prisons were primarily punitive institutions that stripped away individuals' liberty. Before the Qing Dynasty, prisons were usually repurposed buildings such as former temples. The general thought was that prisoners should suffer and did not deserve to be treated as valuable human beings; hence, like the prisoners it held, a prison's architectural significance was of little consequence. After the bourgeois revolutions in Western countries, the function of prison buildings evolved in line with social progress. In addition to strengthening the state apparatus, the Qing government improved prison administration. An early agenda item was to improve prison architecture, and that concern subsequently lead to the creation of Capital Model Prison. Model prison was a general term applied to improved late Qing Dynasty prisons modeled after Western and Japanese prison designs. A model prison had two characteristics: first, it was a prison system that followed the Western and Japanese administrative structure of separating the judiciary and the prison itself; and secondly, the main prison building's architectural design follows European and American examples [1]. The Qing dynasty's Capital Model Prison contributed to traditional Chinese prison model transformations and responded to modern prison system trends and development.

Many important historical lessons of contemporary value resulted from the establishment of model prisons during the late Qing Dynasty. Under the guidance of historical materialism, the study of model prison architecture in the late Qing Dynasty is of theoretical and practical significance in strengthening modern and civilized Chinese prison construction. 


\section{PRISON: DEFINITION AND ORIGIN OF REFORM}

\subsection{Prison defined}

In modern jurisprudence, a prison is where criminals are held, and sentences are executed. However, to adequately study the concept of prison, the concept should be treated in both a broad and narrow sense.

Prison in the broad sense refers to institutions and locales where criminals are held or forced to perform hard labor, and the institution is backed by the coercive power of the state. The concept of prison in the narrow sense is "a place for the execution of free sentences": specifically, a place of public creation where people's freedom of movement is restrained by the state's power according to legal provisions. In short, it is a special institution set up by the ruling class to carry out the punishment of convicted criminals according to state law.

In this paper, prison is addressed in the narrow sense and refers to a place where the ruling class detains convicted prisoners; it is the penalty enforcement agency established in accordance with national law [2].

\subsection{Origin of prison reform}

Crime, punishment, and the prison system in modern China have witnessed radical changes during the first half of the 18th century, as evidenced through the lens of the Chinese prison system. This paper explores the profound and lasting repercussions of superimposing both Eastern and Western-derived repentance and rehabilitation models on traditional Chinese crime and punishment methodology, instead of presenting a simple history of prison rules and administration [3]. Prisons reflect a society's notions of law, order, and individual rights, as well as human nature itself and its tractability and capacity to change. During China's tumultuous years from 1895 to 1949 , these notions transformed dramatically.

\section{PRISON ADMINISTRATION CHANGE DURING CRISES AND DEMONSTRATIONS}

After the 18th century when Western capitalist society developed rapidly, legal systems reflected the will of the bourgeoisie and their interests were safeguarded. Their slogans of freedom, equality and fraternity were forceful and powerful, and appeals and movements to implement penitentiary education and improve prisons became global. Capitalist countries represented by Britain, the United States, France, Germany, Japan, Italy, Denmark, Sweden, and Belgium all reformed and improved their prison systems and began to conduct related research. Japan significantly improved its national prisons after the Meiji Restoration. Following the Opium War defeat, China's feudal economic foundation was severely damaged, and around 1901 the imperialist powers intensified their political, economic, and cultural invasion of China while the Qing government became increasingly brutal; it was a time of unprecedented national contradictions. The period between the 1840 Opium War and the founding of the People's Republic of China in 1949 was a period of reflection for modern Chinese prison administrations. During this period, China was reduced from an independent feudal state to a semi-colonial/semi-feudal state, and the nature of society changed drastically, thus marking China's prisons as semi-colonial/semi feudal. Prison reform was imminent and in the ruling classes' interest. Pain and humiliation virtually became the root cause of the contradiction between the purpose of imprisonment and the misdemeanor. Change in the inherent thinking of prison governance was obviously necessary. 


\section{THEORY}

\subsection{Political theory and architecture}

The relationship between politics and architecture is bi-directional: politics may influence architecture, but architecture may influence politics as well [4]. Model prison architecture in China was influenced by the politics of the Great Powers (primarily Britain, the United States and Japan) and their quest for global hegemony. According to Zhongguang [5], prisons in China were mostly houses that had been converted to accommodate the restrictive functionality of prisons [5]. The beginning of the 20th century marked the introduction of formal prison designs in China when the "Beijing Teacher Model Prison" was built toward the end of the imperial dynastic reign in China [6]. It was the first specifically built prison to accommodate structural and functional requirements. After liberation, the prison was renamed to Beijing Prison whose service lasted for four decades. Since the first Opium War, the jurisdiction of the Chinese over British subjects had been a contested issue, with the British refusing to accept China's jurisdiction over its subjects living in China. This was one of the major triggers of the 1840-1841 military conflict between the two countries [7].

Western countries regarded China's court proceedings and legal punishment as both barbaric and intolerable. Therefore, they insisted that China cede its sovereignty over legal matters pertaining to European subjects in China. Consequently, extraterritoriality was an issue included in the 1840 and 1860 settlements between China and the Great Powers, thus allowing foreign subjects to be tried by their respective foreign consuls. Apart from rendering foreign merchants and missionaries immune to Chinese authorities, this had the effect of perpetuating the influx of foreign jurisprudential thought and practice, leading to the emergence of a substitute legal system. Moreover, using their military leverage, Britain, the US, and Japan pressed for legal reforms to be included in treaties signed with China in 1902 and 1903 [8].

Aligned with this, Qing functionaries and reformers were persuaded that the Chinese state's authority and prestige could only be reasserted by ending extraterritoriality. This required the adoption of western legal practices, and pressure exerted by the Great Powers necessitated the reformation of the country's punishment system. The urgency for this was enhanced by the Chinese state's decline both within and outside its borders toward the end of the 19th century. A new prisons law emphasizing instruction and industrial labor (reformation of the individual) rather than punishment alone was thus passed in 1913 [9], signaling China's eagerness to gain global legitimacy and to be perceived as reformative. The facilitation of transformation that was crucial to establishment of prisons was effected by ministers such as Mr. Xuan Hongci were influential in facilitating prison transformation. Hongci traveled globally, searching for information relevant to the constitutional establishment of prisons. Upon his return, he directed the Ministry of Criminal Justice conversion to the Ministry of Law, and established the Department of Prisons. This enabled governmental authority to oversee the national prison administration [5].

From the Foucaultian perspective in which a societal group is studied in relation to power, this may reflect the need to have a group subjected to an idea via soft coercion and to be productive for the idea to be useful [10]. One major consequence of the pressure imposed by the Great Powers was that the Chinese punishment system was reformed in line with a western template [7]; the Beijing Prison design was based on Great Britain's Pentonville Prison (Fig. 1). 

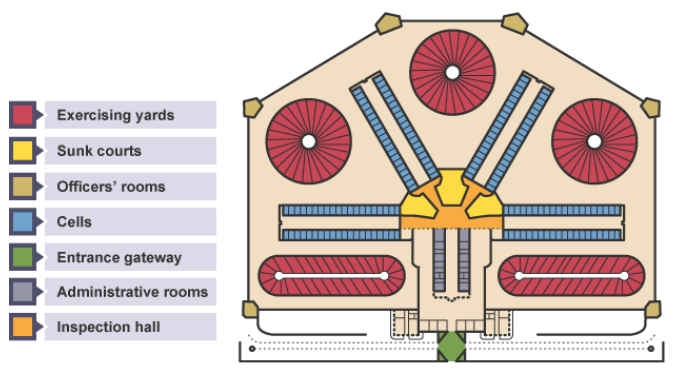

Figure 1: Layout of the Pentonville Prison [11].

A visual depiction of the Beijing Prison in 1917 is presented below (Fig. 2). Note the cellblock radiating from the central tower.

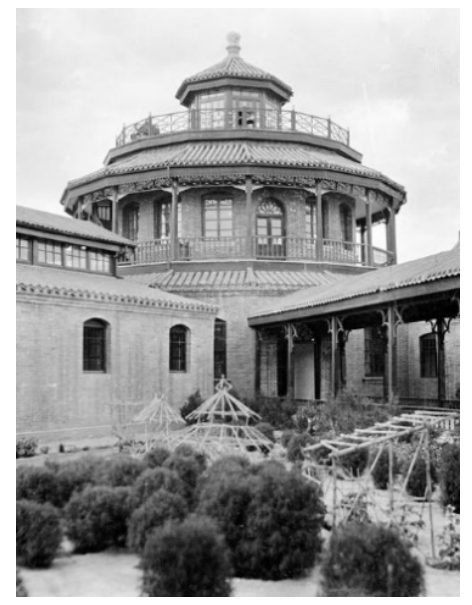

Figure 2: Beijing Prison in 1917 [12].

Political influence on prison architecture was manifested in this manner. Although the Hubei model prison was the first model prison in China, the Beijing Prison whose construction began in 1909 and was completed after the Xinhai revolution, was the most famous of the model prisons in China [7]. As an example of architecture's influence on politics, the Beijing Prison had distinct architectural attributes which helped express the preferred political ideology of the late Qing era, and subsequently, the Republican era.

A layout plan of Beijing Prison is presented below (Fig. 3). According to Kirby et al. [7], London's Pentonville Prison served as the model. Their similar layouts can be seen below.

According to Dikotter [14], the two predominant prison architectural models in China were the radial/fan-shaped (shanmianxing) (Fig. 4) and crucifixion (shizixing) designs. As shown in the Pentonville Prison plan (Fig. 1), Beijing Prison utilized the fan-shaped plan (which was a variation of the cruciform shape), with blocks of cells radiating from the center (two central points). 


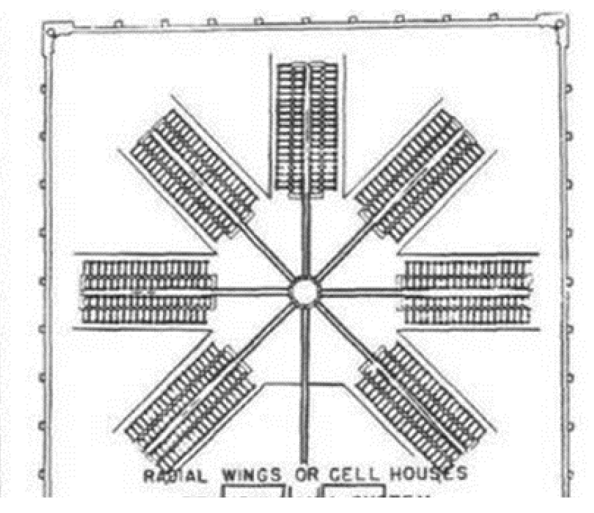

Figure 3: Schematic layout of Beijing Prison formerly known as Jingshi Prison [12].

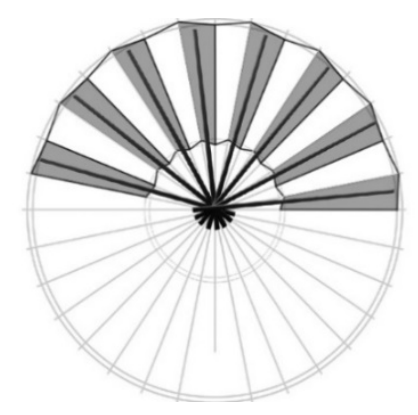

Figure 4: A fan illustrating the radial shape (shanmianxing) [13].

According to Kirby et al. [7], the prison spanned $300 \mathrm{~m}$ from east to west, was $330 \mathrm{~m}$ in length from north to south, and consisted of three sections. The wings which radiated from the center contained 165 individual, and 40 communal prison cells. The prison was designed in accordance with the Panopticon principle, as elucidated by Bentham [15], an architectural design that assured optimal visibility and surveillance [7].

The basic idea behind such visibility was to attain panoptic control in line with the Panoptic Control Theory which asserts that individuals (inmates) are more likely to adhere to established rules and norms when they are aware of being observed [16]. Given the configuration of the prison architecture, prisoners were transformed into individual objects within the "economy of observation," with no opportunity to hide from observation. From a political perspective, the Panopticon has also been interpreted as a surveillance tool for control and subjugation in a disciplinarian society [14]. This appears to reflect the Foucaultian view of the contemporary penal system's evolution, with the agency of punishment shifting from the corporeal to the spiritual (i.e., from a public, visible, bodily form of punishment to a private, invisible, disciplining of the soul). Bodily incarceration was previously viewed as the state's absolute power over its citizens, but Panopticon control illustrates the use of strict discipline to achieve social control, the overriding aim being to forestall future crimes rather than to achieve revenge [10].

Architectural prison design incorporating a visible and clear center and multiple subcenters also reflected a prison's hierarchical order, providing unambiguous structures for the 
ordering, separation, and regulation of inmates within the prison [7]. According to Dikotter [14], the architecture provided a high degree of symmetry and regularity - architectural aspects meant to mirror a sense of order the prison intended to instill in its inmates - along with a sense of character. Prison architecture was also meant to enforce transparency and impermeability, two of the most widely articulated and valued attributes within Chinese society.

While transparency was achieved through Bentham's Panopticon design principles that allowed for around-the-clock inmate observations by wardens, impermeability reflected the need to prevent prisoners from escaping. This was achieved using thick brick walls, reinforced concrete, iron gates, long corridors (Fig. 5), and central towers, creating a bastion that contained evil within and protected outside society from moral decay. It was a factory for the industrial production of morality [14].

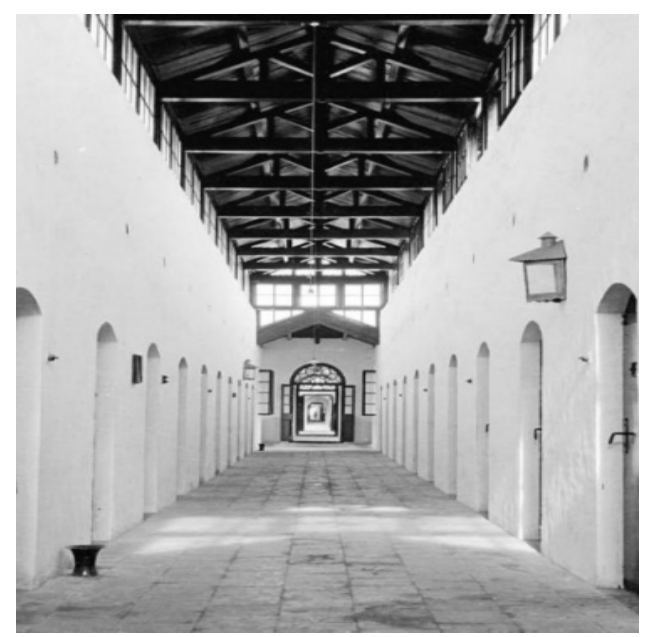

Figure 5: Beijing Prison corridor in 1917 [12].

The separation of cells and use of single cells created spaces for solitary confinement viewed as essential to discourage vice and encourage virtue. It was thought that solitary confinement would prompt cathartic reflection and silent meditation, and in so doing would enable an inmate to appreciate the full value of liberty. It could also prevent other inmates' undesirable influences and place the inmate in the therapeutic hands of wardens, hastening the inmate's reformation. It was also believed that solitary confinement could break an inmate's evil instincts and resistance, and thereby transform his/her character [7].

The entire architectural system not only facilitated the achievement of penological goals, it led to the fulfilment of broader political goals. As Dikotter [14] reported, architectural features helped to underpin the new communist regime's penological principles and acted as a tool to pursue Confucian ideals of a cohesive, virtuous and ordered society. From the Foucaultian Theory of Power perspective, prisons provided a venue wherein new social relationships between felons and the state could be forged, the formation of such relationships being mediated within the ubiquitous and ingrained microphysics of power.

Power in the modern age is comprised of much more than punishment and coercion; it also incorporates various cultural techniques to persuade and manipulate subordinates. Accordingly, the dominant discourse is expected to generate narratives, symbols, and 
representations through which most of the society's cultural and scientific products are manipulated [10]. Within the Chinese context this was expected to spread from a prison which was regarded as a miniature society, to society in general. As such, the prison was also used by the China nation state as a laboratory where "a new subjectivity of the loyal, good, disciplined citizen was developed" and for the Chinese nation-state to arrange a system of representation and formulate new conditions for "individualized self-representation" [14].

\section{CHOICES UNDER PRESSURE TO ABOLISH CONSULAR JURISDICTION}

Since the 18th century and during the development of the bourgeois revolution, bourgeois legal culture gradually formed with bourgeois humanism as its core. Amid the slogans of freedom, equality, and fraternity, the penal system has undergone major changes. Reform movements using prisons for penalty enforcement quickly emerged on the European continent; penalties characterized by humanity, probation, and education became popular in prison systems. "From humiliation to probation," became the concrete manifestation of humanitarianism in prison governance under the western rights concept. This transformation also took place in China during the early 18th century. It represented not only a "learning from the West" mentality of Western prison civilization, but also a chosen mix of Western and Chinese prison systems, the latter carrying the historical identity of an ancient prison governance spirit [17]. Whether it was from a sincere belief in traditional attachments or to make reforms run smoothly, the tradition of benevolent governance provided an effective ideological foundation and psychological support for the acceptance and recognition of probation thought.

Starting in the 1840s, the forced signings of one-sided treaties damaged China's judicial sovereignty, one manifestation being the establishment of other countries' consular jurisdictions in China. Western prisons set up by judicial organs of colonial countries appeared one after another, ultimately influencing the modernization of Chinese prisons. While safeguarding the national sovereignty and interests of the country to some degree, prison administration reforms were strongly political in nature and undoubtedly determined the basic character of future reforms.

\section{CAPITAL MODEL PRISON}

During the closing days of the Qing Dynasty, the government launched the "New Deal" and "Preparatory Constitutionalism" campaign in an effort to save its regime. A series of judicial reforms were enacted as an important part of this political reform, one of which addressed prison administration. When the Republic of China came into power, a series of new prison reforms were decreed for political and diplomatic reasons and were based on the late Qing Dynasty's prison administration's practices. The new reforms greatly exceeded earlier ones in terms of scale, implementation, and longevity.

Capital Model Prison was selected for the present paper because it has been an exemplary model of national prison reform since the end of the Qing Dynasty [18], and it represents prison reform trends during the Republic of China. Prisons commonly symbolize brutality, darkness, and corruption. They are violent tools set up by a ruling class to maintain dominance, and the institutions can be conveniently separated physically from civilization. As a reflection of China's modernization, prisons become a yardstick to measure the degree of a country's social civilization; the degree of prison civility is an important coordinate for measuring a society's transition to modern civilization. The modern civilization consciousness it realistically embodies reflects China's modernization process. Some of the problems exposed during the transformation also reflect China's other deep-seated problems. 
As the first modern prison in China, Capital Model Prison was built in the late Qing Dynasty and was renovated in the early years of the Republic of China [19]. Due to regime changes, its identity has undergone a series of names from Capital Model Prison, Capital No. 1 Prison, Hebei No. 1 Prison, Peiping No. 1 Prison, Beijing Hebei No. 1 Prison, and Beijing No. 1 Prison. As a new-style prison, it differs from those that have come before, especially in terms of management. It has become a prison reform movement model representing the late Qing Dynasty and the Republic of China.

Due to its intended function, multiple factors had to be considered when selecting the prison location. The prison was set outside Beijing to the southwest, a relatively sparsely populated area that is relatively open, low-lying, and conducive to prison placement. During initial construction, large trenches were dug around the perimeter to both prevent escape and to accumulate water. Having been designed by Japanese prison scientist Koizumiro Ogawa (小河滋次郎), the architectural style resembles that of Japanese prisons [20].

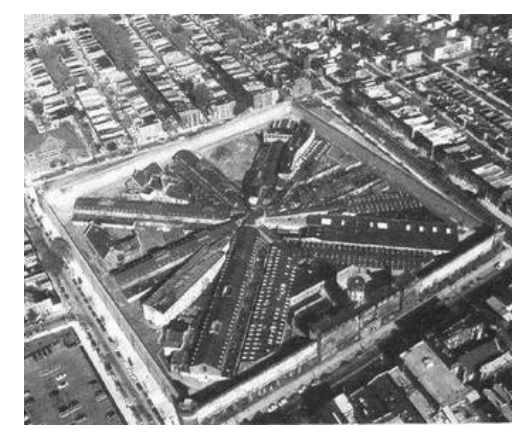

Figure 6: Aerial view of the Capital Model Prison (The Beijing Prison) showing the layout of the entire site [21].

The main gate is oriented toward Yongding Gate Street in the east, creating an east-west main axis, and the entire site is divided into front, middle, and back areas. The gate constitutes the central axis of the front area. South of a rain channel inside the gate is the guard and teaching center, and to the north is the exhibition center and reception room. To the west are two guard dormitories facing each other. A second entrance leads to the middle area and the main central office building. The back area contains the main prison. Additionally, there are two special prison areas: the disease surveillance room to the north, and the female room to the south of the prison room (the original plan for the infant prison) separated by two walls.

A comparative layout of the general prison plan is shown in Fig. 8.

In 1918 a new section was built to the north of the site along with a north gate and an agricultural plantation to the west. Within the prison there are workshops for prisoner use as well as wards, bathrooms, warehouses [23], and both single-living and multi-living cells. Great importance was given to the transformation of Capital Model Prison during the Republic of China, and new workshops, main rooms, and other prison buildings were required additions. The size and dimension of materials used in the construction was highly regulated, as well as certain materials, depths, wall thickness, etc. Prison buildings at that time were mainly made of brick and wood which were relatively simple and practical, but limited by factors such as the national economy, finances, and available construction technology. 


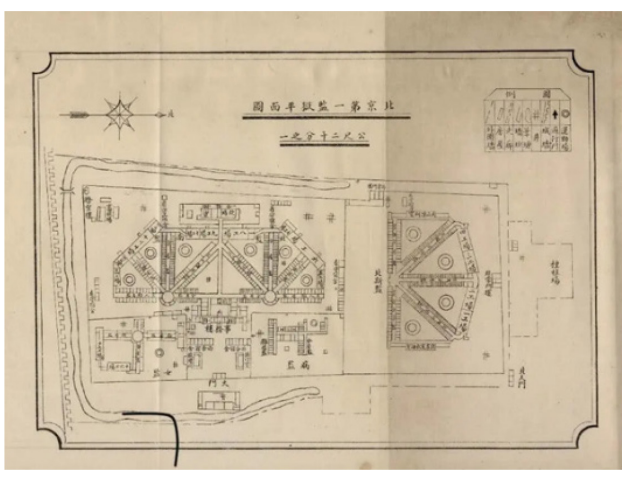

Figure 7: The layout of a Capital Model Prison [21].

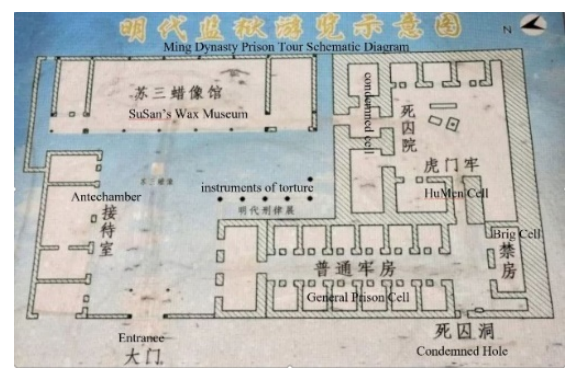

Figure 8: The layout of a general prison in Chinese feudal dynasty [22].

While building new prisons and updating older ones, the Republic of China government mandated specific requirements that found their way into the Measures for Amendment and Improvement of Old Prisons (修正改良旧监所最低限度办法) [24]. The Republic of China's fiscal revenue was extremely limited and was primarily used to maintain a huge military force and support an ongoing civil war, or to repay foreign and domestic debts. Consequently, the national government was unable to invest large amounts to adequately renovate outdated prisons; they could only afford to make modest improvements. In 1912, the Republic of China government formally opened Capital Model Prison and began to accept prisoners and changed its name to Beijing Prison. Yuanzeng Wang, the first warden, had studied penology in Japan. With China's national economic conditions in mind, he presided over the formulation of a series of rules and regulations covering all aspects of prison management including the institutional setting, prison guard service rules, labor system, reward and payment system, commutation and parole system, and the education and teaching system. It is not an exaggeration to call him the founder of the new Chinese prison system.

As noted above, Capital Model Prison was in a low-lying damp area. Drains installed when the prison was built had been clogged for years, inevitably producing many infectious agents living in stagnant reed filled pools that could lead to an epidemic. Moving the prison to a more favorable location was not possible; therefore, Yuanzeng Wang opted to fill the ditch, convert what remained into a gutter, and installed a small floodgate. Yuanzeng Wang objected to soil sleeping platforms traditionally used, believing they contributed to unpleasant smells, and because Beijing is severely cold in the winter and there were many 
prisoners, he felt the large quantity of firewood burned for warmth was not conducive to the health of the prisoners. He therefore suggested that heating pipes be installed in the prison area. Unfortunately, his suggestions were not fully realized until 1922 because of funding issues. Yuanzeng Wang made prisoner health the forefront of his prison work. His recommendations were based on advanced penology theories that embodied humanitarianism and civilized notions absent in prior Chinese prison management. It was more than a decade later when the Capital Model Prison facility upgrades were completed, a delay Yuanzeng Wang greatly regretted. He did not expect quick success when attempting to educate criminals; he approached the task through a series of steps: first, improve the prison environment and sanitary conditions to protect criminals' basic physical health [25]; second, formulate and strictly implement work, rest, diet, and related systems, and build playgrounds to improve criminals' physical fitness; and third, after achieving the first two goals, instill a sense of ethics in prisoners, and teach them a means of earning a living. The three-step procedure accounts for why this prison has been effective in educating criminals [15].

\section{CAPITAL MODEL PRISON AS A GOVERNMENT TOOL}

As a state entity and symbol of legal authority, a prison must be tangible and meet basic social requirements. Without a basic understanding of prison facilities, it is impossible to discuss the implementation of execution law and criminal policies, nor probation and humanity issues. Unlike most other building types, a prison itself has no social class structure; its overriding purpose is to serve the ruling class and their objectives [26]. It is a tool of dictatorship. Capital Model Prison was built on the eve of the 1911 Revolution, and its purpose was very clear: a prison for revolutionary parties who opposed the Qing government. It was completed in 1911 when the Revolution of 1911 overthrew Qing Dynasty rule and the prison became the national government's tool - a place to detain progressives. After the People's Republic of China's founding, the nature of the regime fundamentally changed. The prison became a punishment and reform institution for hostile domestic and foreign individuals who endangered national security, and for those who undermined public order or lives, and property. For the Chinese, the prison was not just a building; it was a symbol of national power and the light of revolution. The Qing government's prison reform was based on the construction of prison execution facilities, legislation customization, and the exploitation of talent. Barbaric prison executions were linked with concepts of humanity, probation, and civilization. However, when the old system was eliminated, the prison situation did not fundamentally change after the introduction of Western thought, mainly because old prison management methods and the people who used them were still important components of the system. The desire for reform ran counter to actual results. Through reform at the beginning of the 20th century, various constraints led to tortuous development. Today, as the prison reform continues, basic elements should be understood in order to promote its effective implementation as a government tool.

\section{CLAIMS AND REFLECTIONS IN JUDGING THE PROS AND CONS OF CAPITAL MODEL PRISON}

\subsection{Prison buildings are one of the instruments of a hierarchical dictatorship and are an integral part of the state apparatus}

Like any other type of building, prison architecture is not class-specific in itself; it is characterized by the fact that as an instrument of dictatorship, it has always been in the hands of the ruling class [27]. Capital Model Prison built just before the Xinhai Revolution had a 
clear purpose: to serve the interests of the ruling class. However, when it was completed in 1911 just as the Xinhai Revolution was overthrowing the Qing court, the building became an instrument of dictatorship for the Nationalist government. After the fall of the Beijing government, it was again used to imprison progressives. In this sense, prisons are also a special type of school. In this respect, the role of Capital Model Prison has won international acclaim. Hence, it cannot therefore be said that the prison building has "any attributes of its own"; it serves whoever takes control of it and can be regarded as a neutral and material byproduct of the current society.

\subsection{Capital Model Prison is a breakthrough in Chinese prison architecture}

Following the bourgeois revolution when society progressed and laws were improved, the perceived function of prison buildings also changed [28]. In the Qing court's "New Deal" measures that usurped foreign countries strengths to make up for China's weaknesses, the strengthening of the state apparatus had to be accompanied by prison improvements. Capital Model Prison was therefore a major step forward in Chinese prison architecture and the emancipation of human rights.

\subsection{Capital Model Prison is a testament to the development of modern} architecture in Beijing and deserves preservation

Built more than 80 years ago, the Capital Model Prison building has served for more than 40 years after the establishment of New China, becoming a rehabilitation center for criminals in China [29]. Mirroring foreign architectural experience, it was the first innovative prison of exemplary quality in modern times.

\section{CONCLUSION}

The creation of the model prison in the late Qing Dynasty created a new chapter in the modern history of Chinese prison architecture. Some of the new architectural innovations emerging because of the adoption of the Beijing model prison included: the adoption of the radial/fanshaped design, the separation of cells (which radiated from the center), and the pursuit of the design principles of the Panopticon with overriding focus on visibility.

Other architectural features included: a visible and clear center and multiple sub centers, use of a high degree of symmetry and regularity, thick brick walls, reinforced concrete, iron gates, long corridors, and central towers. The new prison vividly illustrated the relationship between architecture and politics. Its concept of prison architecture and adaptations of architectural rules had exerted a profound impact on the successive reigns and dynasties such as Peking warlord government and KMT government. It also brought an end to the traditional Chinese model of prison architecture and provided the pavement for the beginning of modern prison architecture in China by combining the styles of Western buildings.

The model prisons created in the late Qing dynasty were in line with the world's trend of improving prison architecture and conditions, although the starting point was to maintain and save the interests of the ruling class, which was no doubt a utilitarian one. However, it should be acknowledged that the establishment of model prisons in the late Qing dynasty was a major step forward in breaking with the traditional model of prison architecture. Meanwhile, the capital prison endeavors to educate and illuminate prisoners instead of solely punishment. This breakthrough may not have reflected the basic intentions of the legislators of the time, but it resulted in putting an end to more than two thousand years of jailhousestyle management under the feudal system, thus making a direct transition to modern 
prison management and ultimately laying the foundations for the modernization of prison management in new China.

\section{REFERENCES}

[1] Bie, Z. \& Ma, X., Research on the architectural layout and construction techniques of Mixian County Ya prison based on ancient Fengshui architectural culture. China Cultural Heritage, (3), pp. 99-104, 2019.

[2] Waller, I. \& Chan, J., Prison use: A Canadian and international comparison. Criminal Law Quarterly, 17(1), pp. 47-71, 1974.

[3] Li, X., The construction of the model prison of the capital in the Qing Dynasty. Research on the History of Qing Dynasty, (3), pp. 148-156, 2019.

[4] Stankovic, D., Tanic, M., Kostic, A. \& Nikolic, V., Balcan cities, political influences and architecture: The case of Serbia. ACE Journal, 2(10), pp. 3-11, 2017. DOI: $10.18503 / 2309-7434-2017-2(10)-3-11$.

[5] Zhongguang, J., Review of the first new type prison building in China: The Capital Model Prison. Journal of Beijing Institute of Civil Engineering and Architecture, 1, 1998.

[6] Zhou, J., The Chinese correctional system and its development. International Journal of Comparative and Applied Criminal Justice, 15(1-2), pp. 15-32, 1991.

[7] Kirby, W.C., Leutner, M. \& Mühlhahn, K., Global Conjectures: China in Transnational Perspective, LIT Verlag: Münster, 2006.

[8] Gelber, H., Battle for Beijing, 1858-1860: Franco-British Conflict in China, Springer: New York, 2016. DOI: 10.1007/978-3-319-30584-4.

[9] Spence, J.D., The Search of Modern China, W.W. Norton \& Co. Inc.: New York, 1990.

[10] Driver, F., Power, space, and the body: A critical assessment of Foucault's discipline and punish. Environment and Planning D: Society and Space, 3(4), pp. 425-446, 1985. DOI: $10.1068 / \mathrm{d} 030425$.

[11] BBC, Methods of punishment, 2021. https://www.bbc.co.uk/bitesize/guides/z938v9q/ revision/6. Accessed on: 8 Feb. 2021.

[12] 17 QQ, Beijing prison, 2021. https://line.17qq.com/article/qcewhwtax_p7.html. Accessed on: 8 Feb. 2021.

[13] Patrick, L., Create an illustrated, Japanese style hand fan in photoshop, 2010. https://design.tutsplus.com/tutorials/create-an-illustrated-japanese-style-hand-fan-inphotoshop--psd-9052. Accessed on: 9 Jul. 2010.

[14] Dikotter, F., Crime and punishment in early Republican China: Beijing's first model prison, 1912-1922. Late Imperial China, 21(2), pp. 140-162, 2000. DOI: 10.1353/late.2000.0008.

[15] Miller, J.A. \& Miller, R., Jeremy Bentham's panoptic device. JSTOR, 41, pp. 3-29, 1987. DOI: $10.2307 / 778327$.

[16] Strub, H., The theory of panoptical control: Bentham's panopticon and Orwell's nineteen eighty-four. Journal of the History of the Behavioural Sciences, 25(1), pp. 40-59, 1989.

DOI: 10.1002/1520-6696(198901)25:1<40::AID-JHBS2300250104>3.0.CO;2-W.

[17] Wang, X., The architectural features of model prison in late Qing Dynasty. Journal of Henan Judicial Police Vocational College, 10(3), pp. 15-19, 2012.

DOI: 10.3969/j.issn.1672-2663.2012.03.003.

[18] Mahoney, J., Path dependence in historical sociology. Theory and Society, 29(4), pp. 507-548, 2000. DOI: 10.1023/A:1007113830879. 
[19] Holbig, H. \& Gilley, B., Reclaiming legitimacy in China. Politics \& Policy, 38(3), pp. 395-422, 2010. DOI: 10.1111/j.1747-1346.2010.00241.x.

[20] Yang, B., Research on Koizumiro Ogawa and the transformation of prison system in the late Qing Dynasty. Journal of China Three Gorges University (Humanities \& Social Sciences), 35(4), pp. 92-95, 2013.

[21] 17 QQ, Beijing prison, 2021. https://line.17qq.com/article/qcewhwtax.html. Accessed on: 8 Feb. 2021.

[22] Yueguan, History of "Guan" language can you distinguish the "three, six, nine, etc." of Qingming prison? 2018. https://www.sohu.com/a/243741442_488248. Accessed on: 20 Mar. 2021.

[23] Melossi, D. \& Pavarini, M., The Prison and the Factory: Origins of the Penitentiary System, Macmillan: London, 2018.

[24] Kiely, J., The Compelling Ideal: Thought Reform and the Prison in China, 19011956, Yale University Press: New Haven, 2014.

DOI: 10.12987/yale/9780300185942.001.0001.

[25] Jiang, J., Liu, B. \& Wang, Y., Exploration and practice of low alert prison. Research on Crime and Reform, (4), pp. 19-30, 2018.

[26] Li, F. \& Qiu, J., The baseline of leniency: Rational rethought on Chinese juvenile criminal justice. Juvenile Delinquency Prevention Research, (4), pp. 29-35, 2013.

[27] Xu, M., On Special Procedures of Juvenile Criminal Justice, Law Press: Beijing, 2007.

[28] Zhang, J., Approaches to juvenile procuratorial works. People's Procuratorate, (23), pp. 165-167, 2011.

[29] Chen, W., Prosecutorial reform in the context of judicial reform. Procuratorial Daily, 23 Jul. 2013. https://www.spp.gov.cn/llyj/201307/t20130723_60693.shtml. 